AUTHOR(S): Roland A. Jalbert

Charles E. Murphy

\author{
SUвmitted to M. L. Rogers \\ Mound Laboratory \\ P.0. Mox 32 \\ Miamisburil. OII 45342
}

MIS I.AIMIR:R

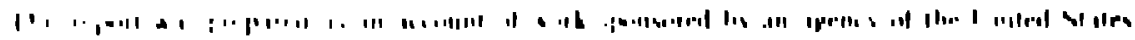

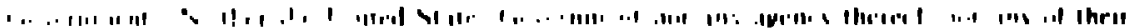

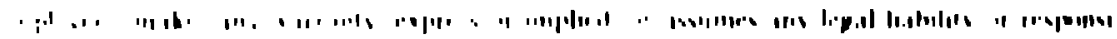

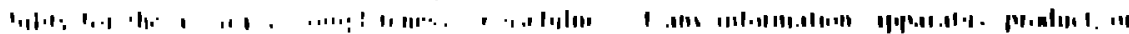

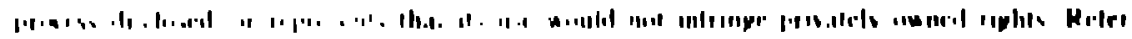

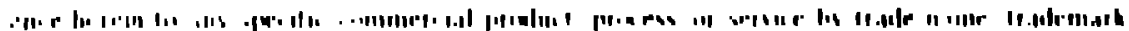

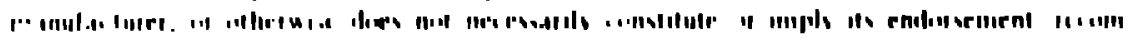

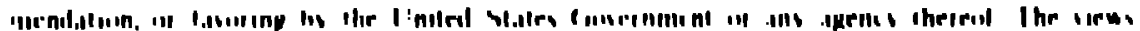

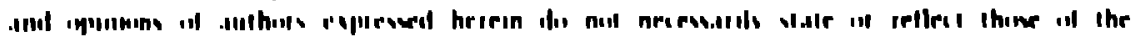
l'nilal Giales fienerninent in ant Iernos therest
\end{abstract}

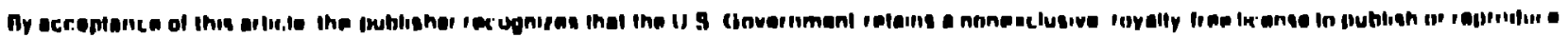

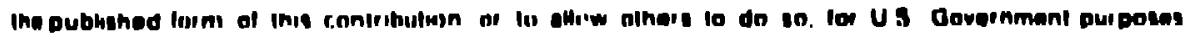




\section{U.S. TEAM MEASUREMENTS DURING THE JUNE 1987 EXPERIMENTAL HT RELEASE AT THE CHALK RIVER NUCLEAR LABOPATORIES,}

ONTARIO, CANADA

\author{
Roland A. Jalbert \\ Los Alamos National Laboratory \\ Los Alamos, NM 87532 \\ (505) 667-0434
}

\author{
Charles E. Murphy \\ Savannah River Laboratory \\ Aiken, SC 29808 \\ (803) 725-5224
}

\section{ABSTRACT}

In June 1987, an experiment was performeil at the Chalk River Nuclear Laboratories in untario, Canada, to study the oxidation of II'I in the environment. The experiment involved a 30-minute release of $100 \mathrm{Ci}$ of $\mathrm{l!} \mathrm{I}$ to the atmos-phere at an elevation of one meter. 'The HTO/I' ratlos were shown to slowly increase dowriwind $\left(-4 \times 10^{-3}\right.$ at 50 meters to almost $10^{\circ}$ at 400 ineters) as conversion of ITT takes place. For several clays after the release, HTO concentra 1 ions in the atmosphere remained elevalded. Preeze-dricol water fiom vegetation simples was found to be very low in tl'I0 imediatrly aftet the release suggesting a very low direct uptakn. nf iTU in air by vegetation. The tritiatorl water concentration increased during the filst sliny, peaking during the second clay filsout $100 \% 600 \mathrm{pr}: \mathrm{i} / \mathrm{ml}$ of watn at 50 meters finm the :aurce) nnd clecteasing by the end of the second say. The organically ixumel teitium comtimunel 1.0 accoumulate dus ing tine pariox foll iwing

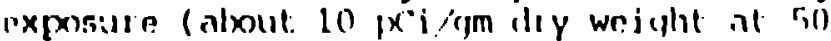
liketers af(ut (w) (nyys).

\section{INTROIXUCTION}

The second in a reties of tocent major

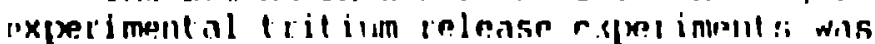

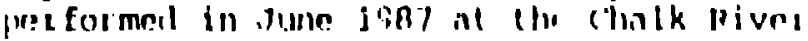

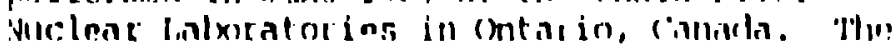

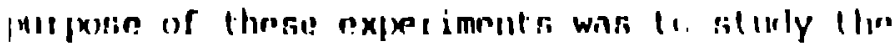

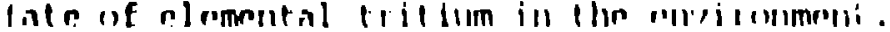

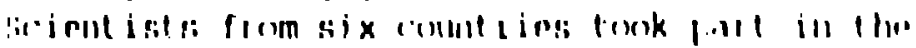

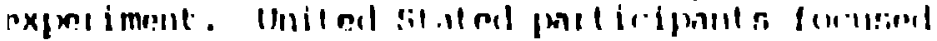

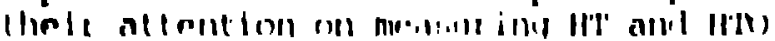

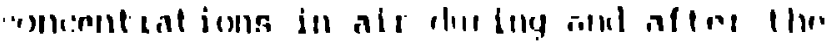
iplease in arkltelon lo allyzime voyntaliem iamples aftel the inlease fol fion walor

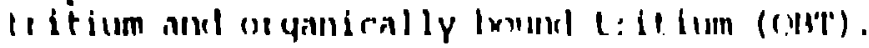

\section{IF. FXPERI MPNI}

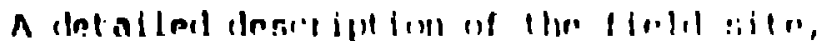

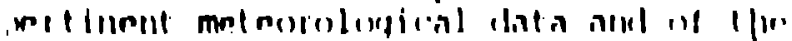

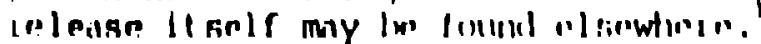

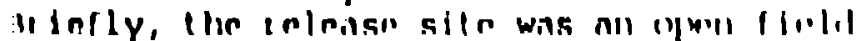

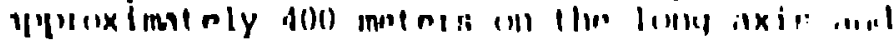

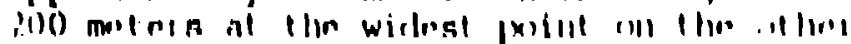

axis. Most of the field was covered with grass and moss with occasional small trees. At the end of the finld farthest from the print of release, the surface soil had been trinsverl leaving an ar 7 with very little vegetation. The field was surrounded by a stanil of mixed conifer and hardwood trees (F1g. I).

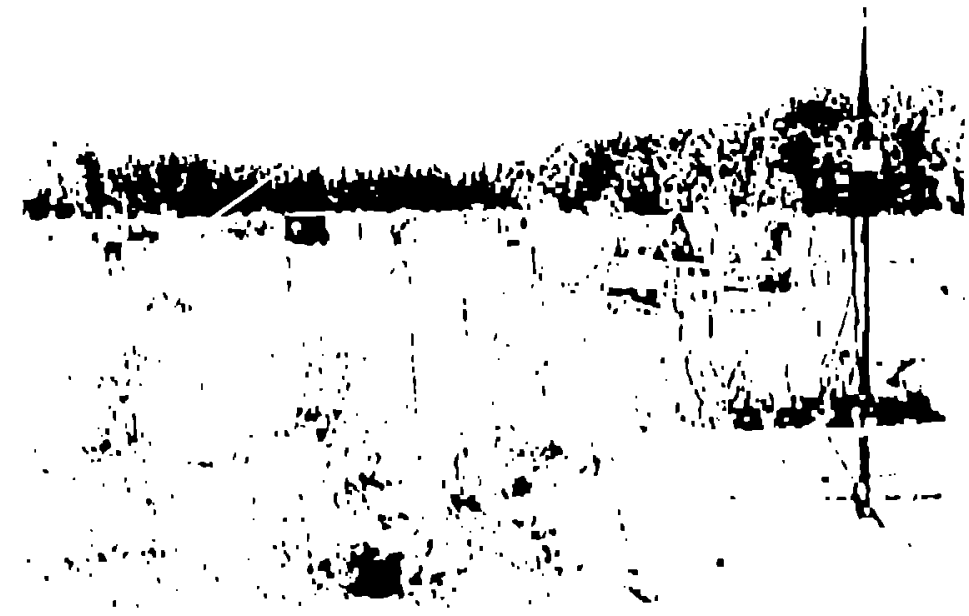

Ficl. 1. Downwind vinw of llor expen innital finld.

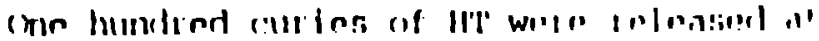

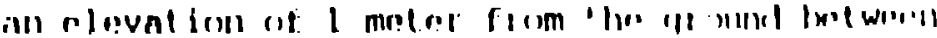

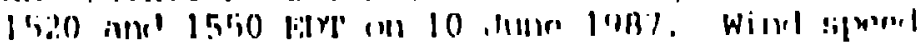

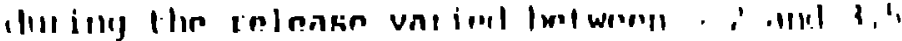

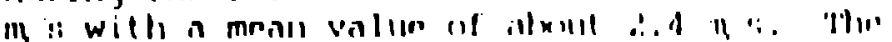

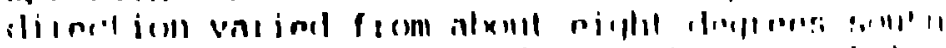

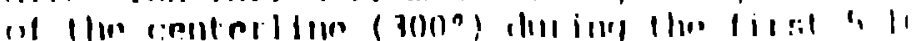

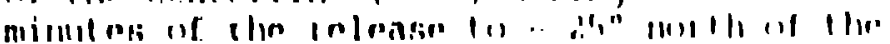

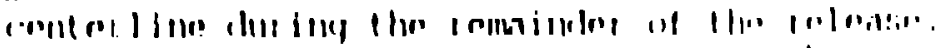

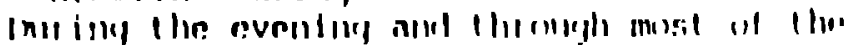

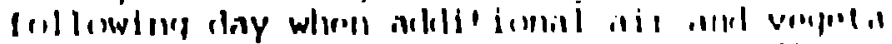

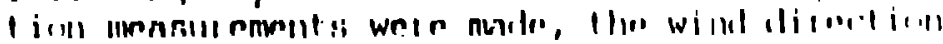

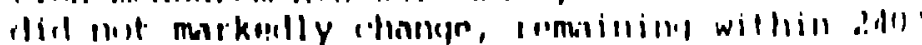

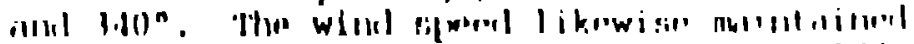

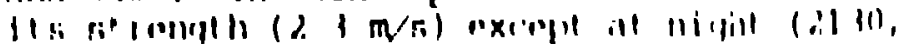

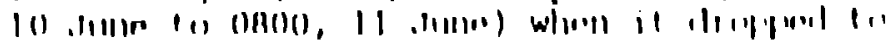

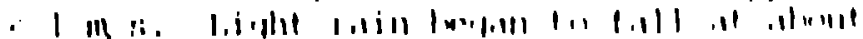

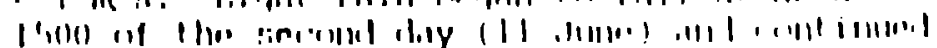

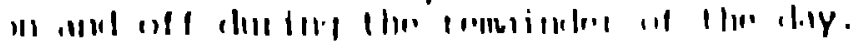

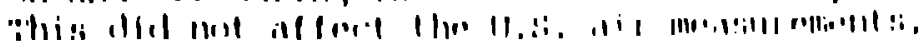

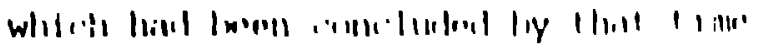




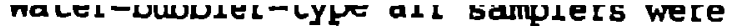
signed and built by the Los Alamos National soratory (LANL) especially for this experiit. Each sampler consisted of three small oblers in series (for HTO) followed by a ated catalyst, three more bubblers (for HT), flor neter and pump (Fig. 2). The bubblers re 20-mL low-background-glass liquicl scintil-. tion vials filled with $10 \mathrm{~mL}$ of water. The talyst cartridge consisted of a copper tube lled initially with irass chips followed by a eclous metal catalyst heated to $400^{\circ} \mathrm{C}$.

llowing the catalyst, cooling coll and ITT bblers were a flowmeter and an air pump. The obler flow rate of $1.0 \mathrm{Lpm}$ was checked after ch sampling run. The catalyst heaters were rned on by plugging them into a local power tlet at least 30 minutes before the samplirg gan. The sampling during the release was itcolled by starting and stopping the pumps notely through cables. Only the first two $\supset$ vials were used for the HTO determination order to eliminate the possibility of adding ckstreaming tritium from the catalyst. For e HT determination, the total tritium colcted during the release was determined by ding all the tritium collected in the HT als during the sampling runs including the o runs after the end of the release. In ittion, the cemaining tritium trapped on the talyst and associated plumbing was leached $t$ at Los Alamos and added to the tritium llected in the vials. The solubility of the in the I'IY bubblers limited the HTO/I' tat in at could be cletermined to a minimum of about: - Three [ANI, samplers were placorl rlose gether it. 50 meters clownivind tiom the source ar the renter line. Ihtre mote, also close gether, wre lnialed at 96 meters and the mining $(w)$ at 183 molors: clowniwiml and 18

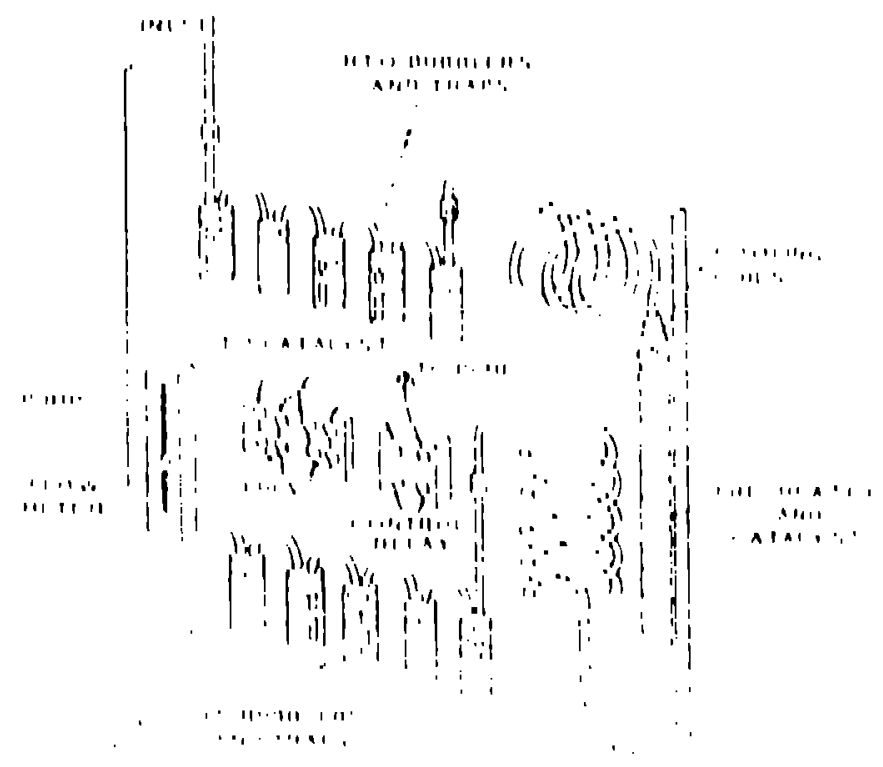

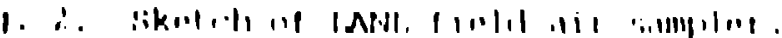

merers apart. Ine reason for bunching the samplers at 50 and 96 meters was to attempt to get a time profile of the tritium air concen.. tration during the release.

Air sampling by the Savannah River I aborin tory (SRL) was done with two HTO/NT samplois (Fig. 3) based on the Oslund-Mason dessign modified for high volume sampling." 'The sytstem consists of a pump which draws 5? litors of ail per minute through two collection cylinclers each filled with 350 grams of Davison $A \Lambda$ molecular sieve. Hydrogen carrier gas i!; acklril to the sampled air stream $(150 \mathrm{cc} / \mathrm{min})$ irefore the air enters the first cylincler, which con tains uncoated molecular sieve for tripping $t h$ IIT. The second cylinder contains pal laclium. covered molecular sieve for H'L. The pallialium catalyzes the oxidation of hydrogen (im-ludim III) to water, which is collected on ll:" : idrur. The samplers were run for a period of (mr hom. At the end of a sampling poi iod tho ("unp) wals stopped, the collection cylinders weic rimoveri and sealed, and fresh collection cylindie s will. installed on the ramplers. The used nollocular sieve was transfercel in the field to ylars: jats which were sealed for later labolatuy annlysis. 'Ihe two samplors wore located meat the conterline at $183 \mathrm{~m}$, ind $150 \mathrm{~m}$ from the? inlonse print.

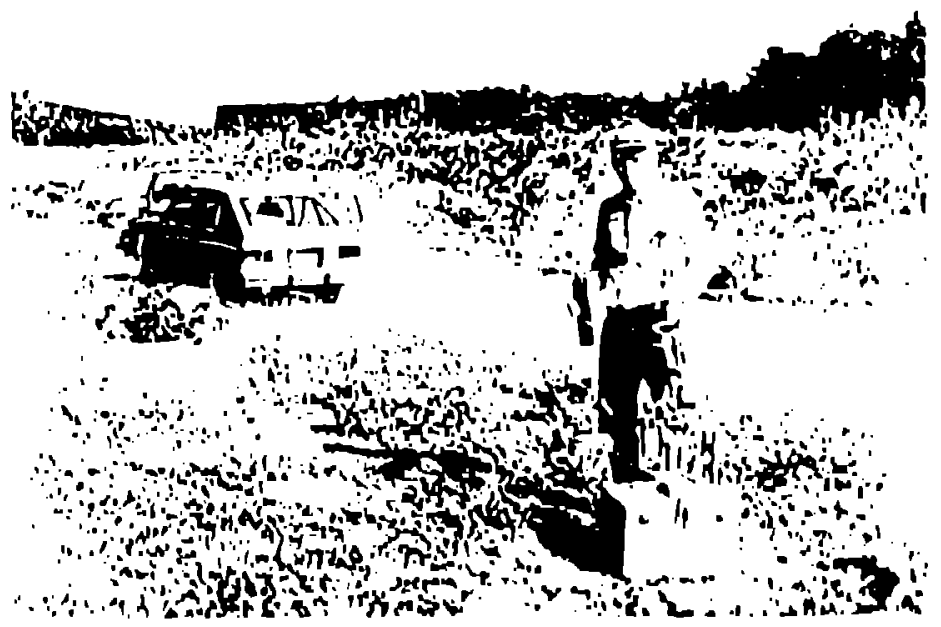

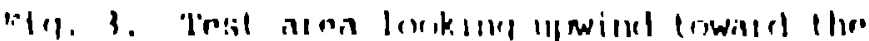

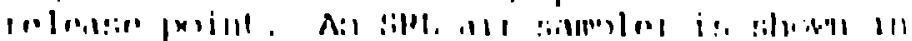

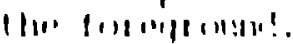

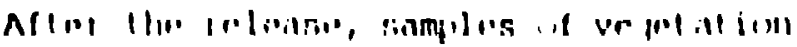
weld lakmll il ', (1),

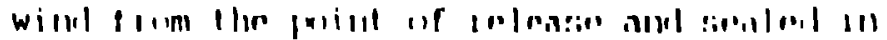

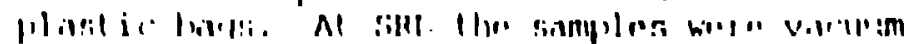

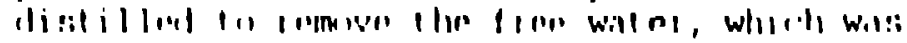

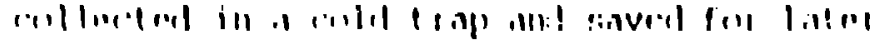

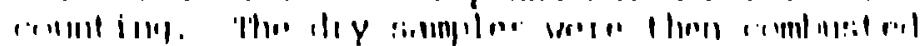

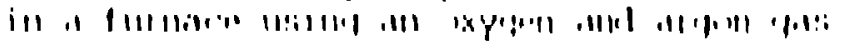

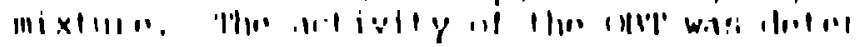

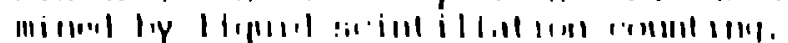

M1::illill::

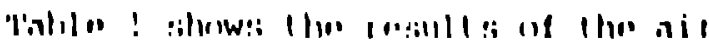


TABLE 1. Results of LANT, and SRL, aír sampling during and after the release.

\begin{tabular}{|c|c|c|c|c|c|}
\hline $\begin{array}{l}\text { Sample } \\
\text { Nimber }\end{array}$ & $\begin{array}{c}\text { Location } \\
x, y, z(m)\end{array}$ & $\begin{array}{c}\text { Sampling Time } \\
\text { II }+(\text { hr:min })\end{array}$ & $\begin{array}{l}{[\mathrm{HT}]} \\
\mathrm{Bq} / \mathrm{m}^{3}\end{array}$ & $\begin{array}{l}{[\mathrm{H} / \mathrm{LO}]} \\
\mathrm{Bq} / \mathrm{m}\end{array}$ & {$[\mathrm{HTO}] /[\mathrm{HT}]$} \\
\hline LANL & $\begin{array}{l}50.5,3.5,0.9 \\
50.5,3.5,0.9 \\
50.5,3.5,0.9 \\
96,2.0,0.9 \\
96,2.0,0.9 \\
96,2.0,0.9 \\
183, \cdots 10,1.0 \\
183,8,1.0\end{array}$ & $\begin{array}{l}H+(0: 1 \text { to } 0: 10.6) \\
H+(0: 10.6 \text { to } 0: 20.1) \\
H+(0: 20.1 \text { to } 0: 29.6) \\
H+(0: 2 \text { to } 0: 11.6) \\
H+(0: 11.6 \text { to } 0: 21.1) \\
H+(0: 21.1 \text { to } 0: 30.8) \\
H+(0: 2 \text { to } 0: 32) \\
H+(0: 2 \text { to } 0: 32)\end{array}$ & $\begin{array}{l}3.0 \mathrm{E}+06 \\
3.2 \mathrm{E}+06 \\
1.7 \mathrm{E}+06 \\
1.3 \mathrm{E}+05 \\
5.7 \mathrm{E}+05 \\
5.6 \mathrm{E}+05 \\
5.1 \mathrm{E}+04 \\
6.5 \mathrm{E}+04\end{array}$ & $\begin{array}{l}1.6 \mathrm{E}+02 \\
1.1 \mathrm{E}+02 \\
5.9 \mathrm{E}+01 \\
1.1 \mathrm{E}+02 \\
3.8 \mathrm{E}+01 \\
9.8 \mathrm{E}+01 \\
2.5 \mathrm{E}+01 \\
8.5 \mathrm{E}+01\end{array}$ & $\begin{array}{l}5.2 \mathrm{E}-05 \\
3.5 \mathrm{E}-05 \\
3.4 \mathrm{E}-05 \\
8.7 \mathrm{E}-04 \\
6.7 \mathrm{E}-05 \\
1.8 \mathrm{E}-01 \\
1.9 \mathrm{E}-0.4 \\
1.3 \mathrm{E}-0.3\end{array}$ \\
\hline 1 & $\begin{array}{l}50.5,3.5,0.9 \\
56.5,3.5,0.9 \\
50.5,3.5,0.9 \\
96,2.0,0.9 \\
96,2.0,0.9 \\
96,2.0,0.9 \\
183, .10,1.0 \\
113,8,1.0\end{array}$ & $\begin{array}{l}11+(1: 50 \text { to } 2: 58) \\
11+(1: 50 \text { to } 2: 58) \\
11+(2: 58 \text { to } 3: 58) \\
11+(1: 50 \text { to } 2: 58) \\
11+(1: 50 \text { to } 2: 58) \\
11+(2: 58 \text { to } 3: 58) \\
11+(1: 50 \text { to } 2: 58) \\
11+(1: 50 \text { to } 2: 58)\end{array}$ & $\begin{array}{l}- \\
- \\
- \\
- \\
- \\
- \\
- \\
-\end{array}$ & $\begin{array}{l}2.6 \mathrm{E}+02 \\
2.1 \mathrm{E}+02 \\
2.0 \mathrm{E}+02 \\
8.3 \mathrm{E}+01 \\
1.0 \mathrm{E}+01 \\
1.0 \mathrm{E}+02 \\
1.1 \mathrm{E}+01 \\
1.0 \mathrm{E}+01\end{array}$ & $\begin{array}{l}- \\
- \\
-\cdot \\
- \\
- \\
- \\
- \\
-\end{array}$ \\
\hline 1 & 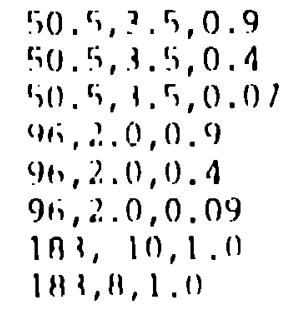 & 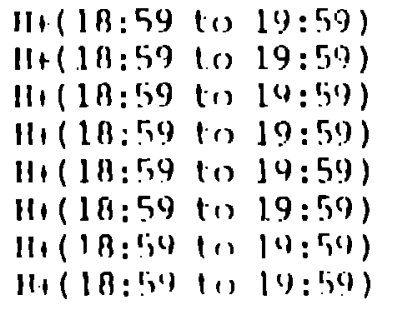 & $\begin{array}{c}\cdot \\
- \\
- \\
. \\
.\end{array}$ & $\begin{array}{l}3.9 F+02 \\
3.6 F+02 \\
1.6 F+02 \\
7.4 F+01 \\
9.0 F+01 \\
2.15+02 \\
2.4 F+01 \\
1.45+01\end{array}$ & $\begin{array}{l}. . \\
. \\
. \\
.\end{array}$ \\
\hline :ill. 1 & $\begin{array}{l}1100,10,10.15 \\
4100,10,11.9\end{array}$ & 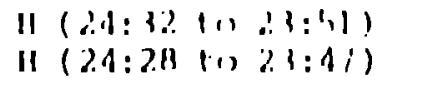 & $\begin{array}{l}\text { B.001: } 11: \\
1.811=01\end{array}$ & $\begin{array}{l}5.2 .26,00 \\
4 \text { AnF, } 1100\end{array}$ & $\begin{array}{l}1.09110101 \\
1.111 .01\end{array}$ \\
\hline & $\begin{array}{l}18(1), 111,1), \because 1 \\
1(11), 31), 11.1\end{array}$ & 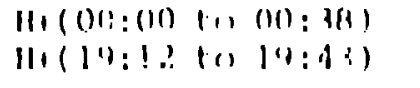 & 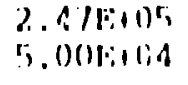 & $\begin{array}{l}\therefore .119 F, 111 \\
4.0(1), 111\end{array}$ & $\begin{array}{l}119: 0.4 \\
0.1)(0): 0.1\end{array}$ \\
\hline & 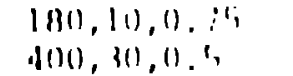 & 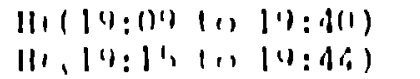 & $\begin{array}{l}2.1150101 \\
5.8710101\end{array}$ & $\begin{array}{l}\text { B. 215.100) } \\
3.12101(10)\end{array}$ & $\begin{array}{l}3.191: 01 \\
\text { i. 1.1: } 111\end{array}$ \\
\hline
\end{tabular}

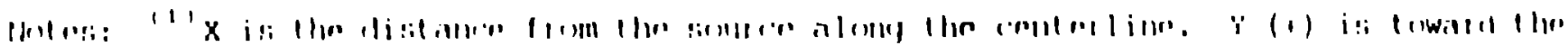

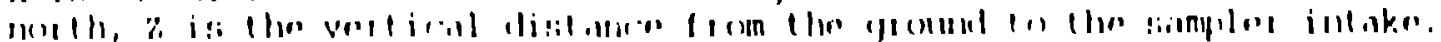

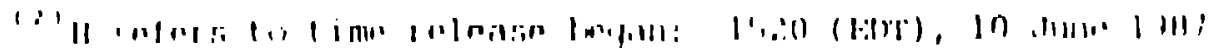

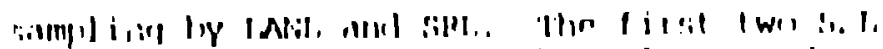

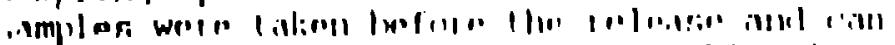

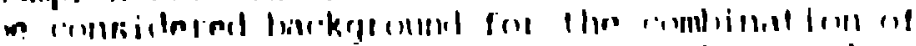

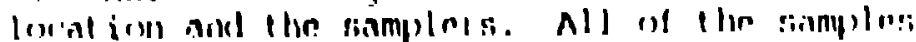

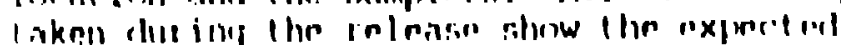

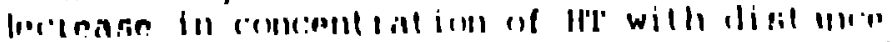

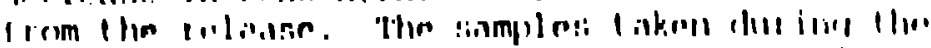

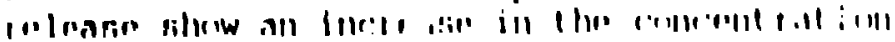

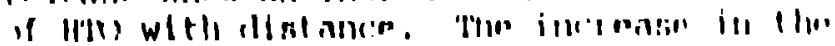

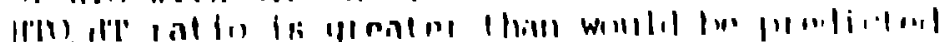

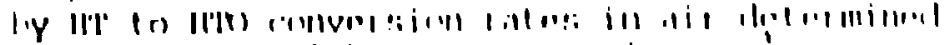

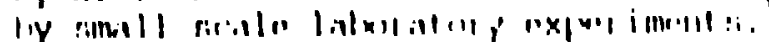

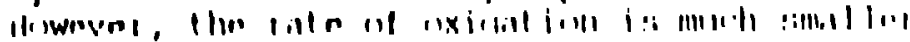

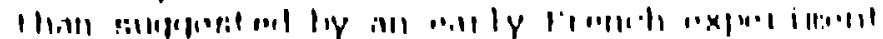

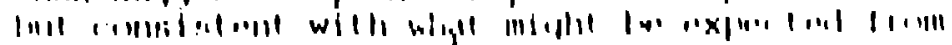

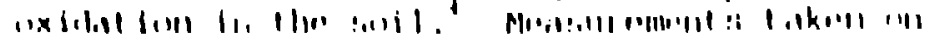

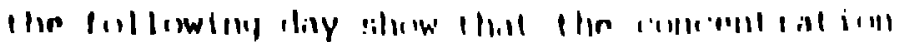

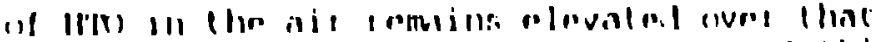

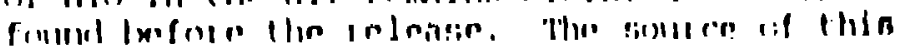

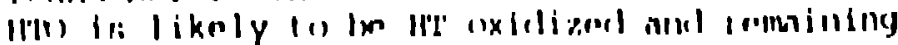

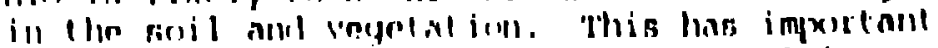

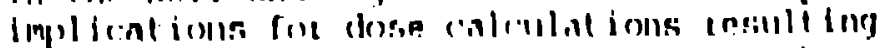

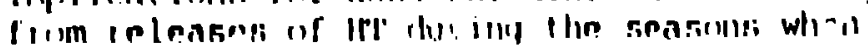

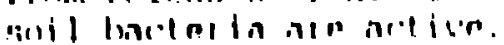

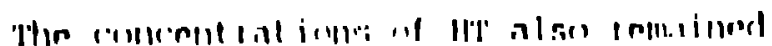

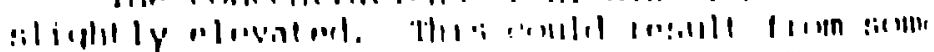

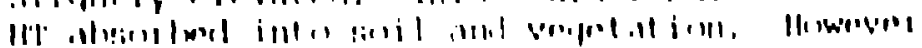

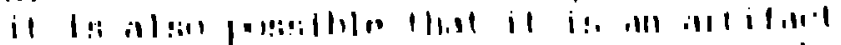

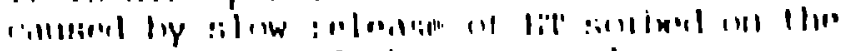
Imel . l

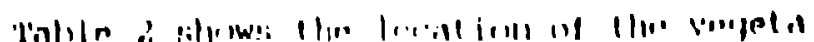

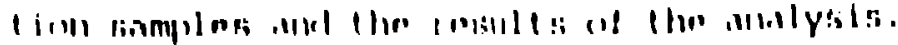


' tABIE 2. Tritium activity in vegetation samples.

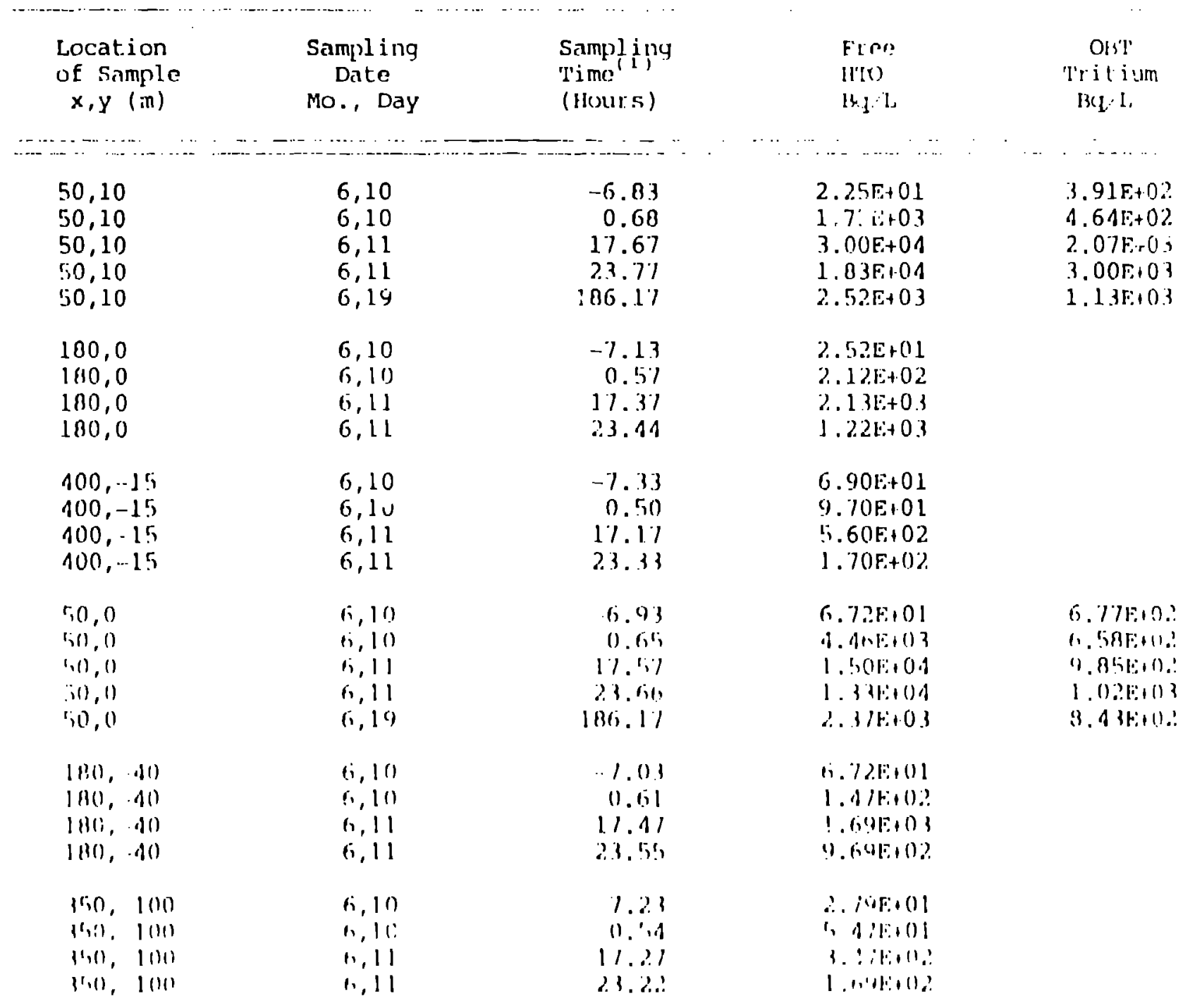

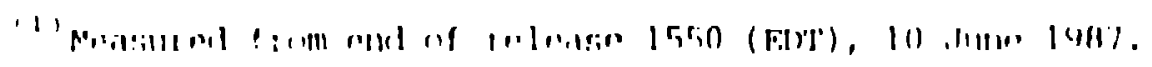

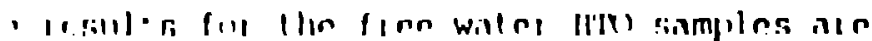

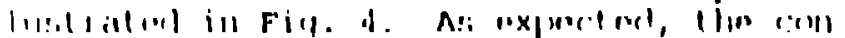

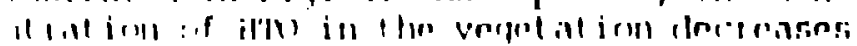

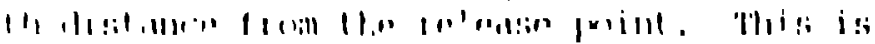

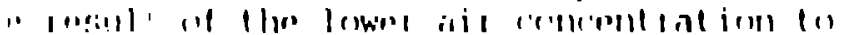

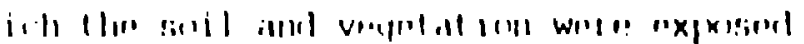

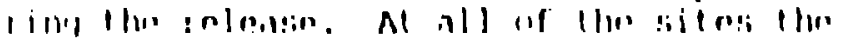

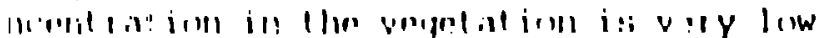

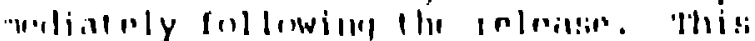

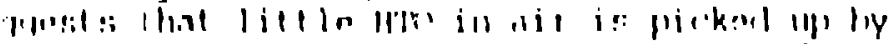

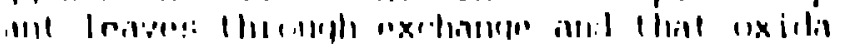

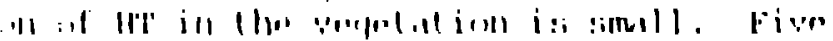

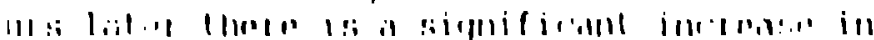

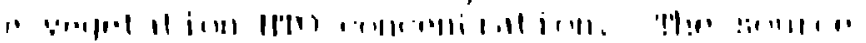

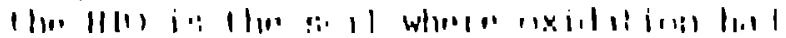

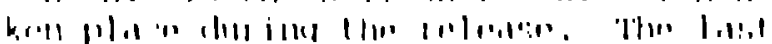

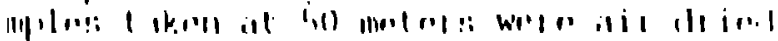

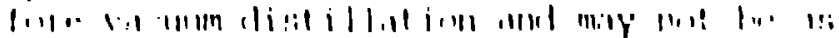

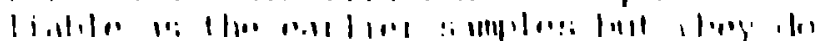

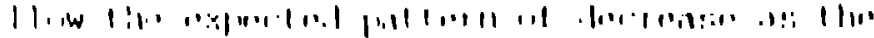

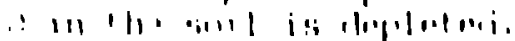

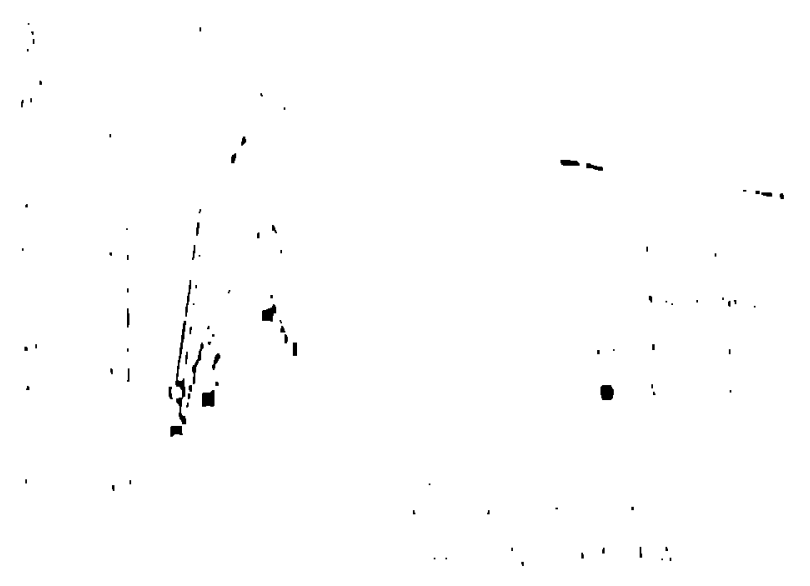

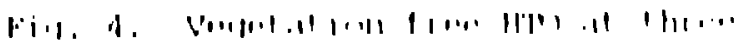

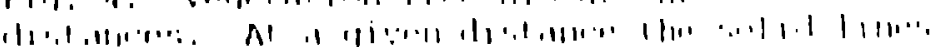

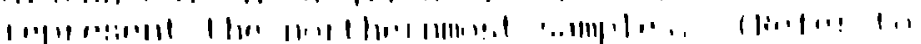

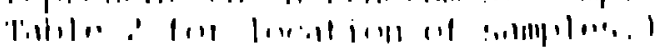


Only at the 50 meter site were the coricenations of organically bound tizitium high ough to be detectable above background using $r$ techniques. 'The OB'T concentration in the ganic material is higher than that found in e plant free-water. 'This may reflect the story of tritium releases in the area. It is so possible that this is another demonstraon of higher tritium of combustion than ee-water tritium under natural environmental nditions. The organically bound tritium (cieased during the first two days after the lease (Fig. 5). Organically bound tritium is ill increasing after the vegetation H7O has gun to decrease. Organically bound tritium is a much slower tuinnover than H'IO in the getalison free-water. It is likely that most the on'l tritium is the result of photosynwet ic: fixation of tait ium fiom the plant llov. rrefore it is not surprising that by the rond wenk, the comsentiation of organically mud tritium has; couleaserl considerally. 'l'he crease can tre explained by the tiamspot of mu? of the latxelod compuncls to other patts of ir plant: and the dilut ion of the lateled plant: Hoital with now growth which is not as highly

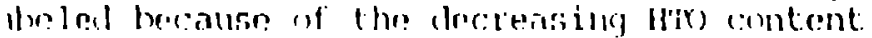
the vegetation.

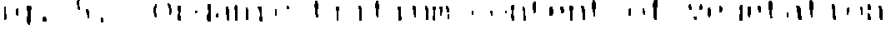
$1,11, n$.
}

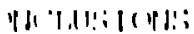

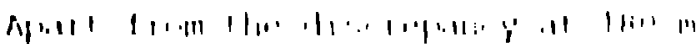

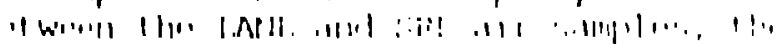

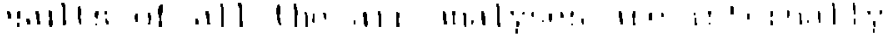

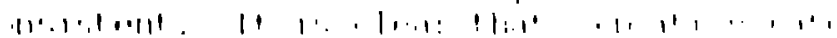

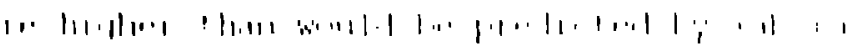

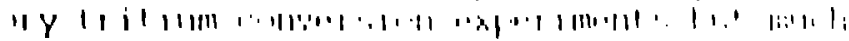

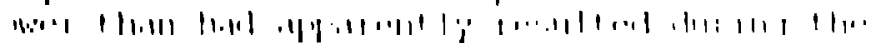

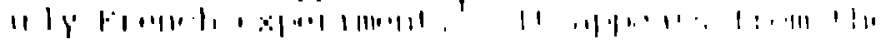

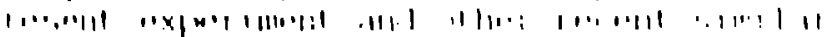

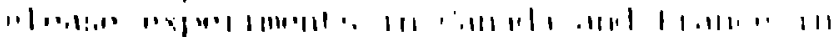

field experiments involving soils that soil bacteria play an important role in clevaling the concentration of HTO in the area of an ' I' ${ }^{\prime}{ }^{\prime}$ release. In spite of the uncertainties in the IITO data presented here, there appears to be little doubt that the numbers are valid within a factor of 2 or 3 al the most.

Figure 6 shows the relationship of IIT $\mathrm{cm}$ centration in air measured by SRL cluring the. release and HTO concentration in the vegetation five hours after the release. The slopes of the concentrations (on log-log paper) are nearly identical to those expected if. soil IIT oxidation is proportional to air ll' collcentration. This adds corfidence to the rate of dectease in IIT measure. by the ait monitors. Indirectly it also ackls redence to the arsettion that conversiun in ait of II' downwind of the release is occurring at a slow rate.

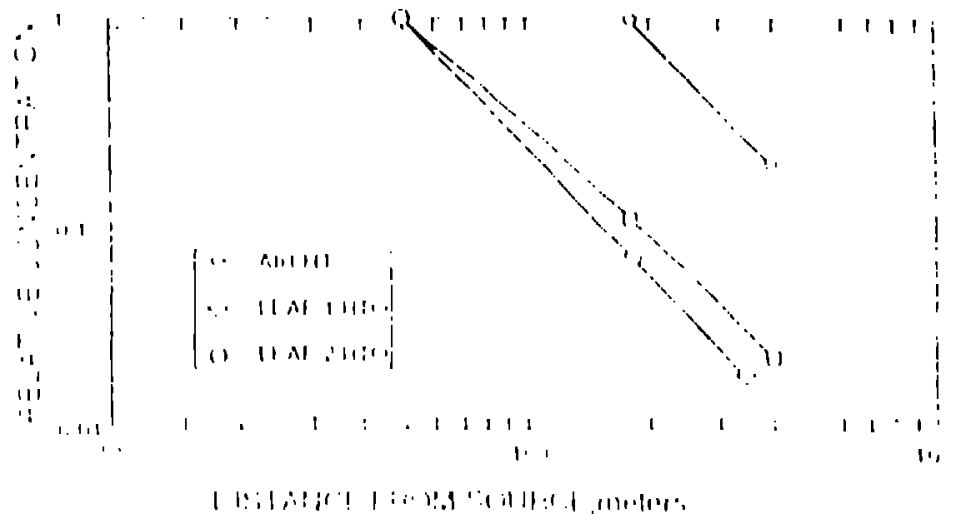

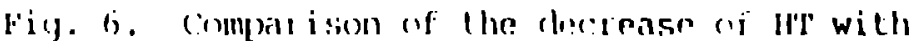

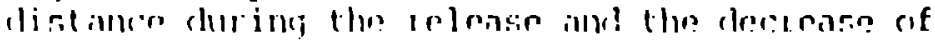

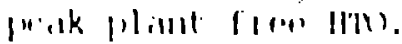

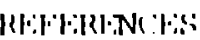

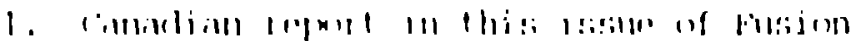
Tro-lumlum.

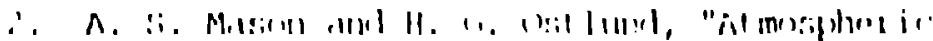

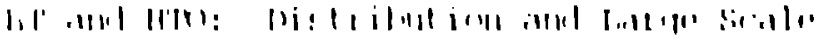

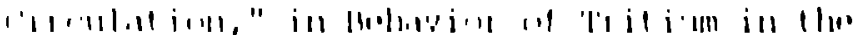
|ll1,

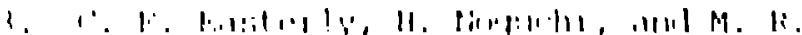

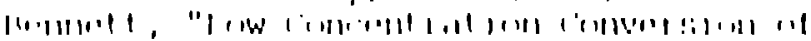

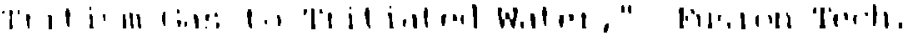
$\because 11$.

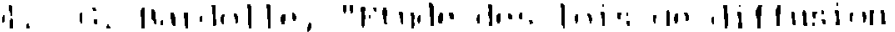

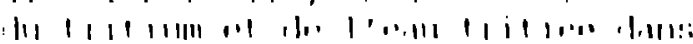

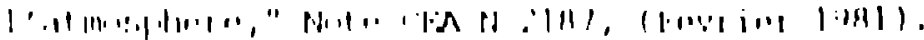

